\title{
HAEMATOLOGICAL ADJUSTMENTS WITH DIURNAL CHANGES IN BODY TEMPERATURE IN A LIZARD AND A MOUSE
}

\author{
Graeme S. Maclean ${ }^{1}$, Anthony K. LeE ${ }^{2}$ and Phillip C. Withers" \\ ${ }^{1}$ Department of Zoology, The University of Michigan, Ann Arbor, Michigan 48104, U.S.A. and \\ 2Department of Zoology, Monash University, Clayton, Victoria 3168, Australia
}

(Received 28 February 1974)

\begin{abstract}
Hypothermic lizards (Egernia cunninghami) showed significant reductions in plasma volume, haematocrit and haemoglobin concentration. The changes in the distribution of red cells were acutely reversible when body temperature was increased.

2. Consequently, there were no significant alterations in blood viscosity (when measured in vitro in a capillary viscometer) between body temperatures of $32^{\circ} \mathrm{C}$ (preferred body temperature) and $20^{\circ} \mathrm{C}$.

3. In contrast, mice (Peromyscus leucopus) showed no significant changes in haematocrit, haemoglobin concentration or red cell count, associated with diurnal torpor.

4. These results are discussed in relation to haemofluidity and optimization of oxygen transport.
\end{abstract}

\section{INTRODUCTION}

ARTIFICIALLY induced hypothermia in homeothermic mammals frequently results in death due to circulatory failure (Johansson, 1967). Formation of intravascular thrombi and increased blood viscosity associated with low blood temperature and elevated haematocrit appear to be contributing factors. Reduction of plasma volume and splenic contraction both contribute to the elevated haematocrit (Kanter, 1968).

Heterothermic vertebrates, on the other hand, have the capacity to maintain cardiovascular function over a wide range of body temperatures. Included among these are heliothermic lizards (Templeton, 1971) and those birds and mammals which hibernate or undergo daily torpor (Hudson, 1973). The cardiovascular systems of heterothermic vertebrates may be adapted to function adequately at low body temperatures in several ways. For example, the hearts of hibernators appear to maintain integrity at lower temperatures than those from non-hibernators (Alpert et al., 1972). Another adjustment appears to be changes in blood viscosity which alter the flow properties of blood. The dependence of blood viscosity on temperature, haematocrit and plasma protein concentration is well established (Merrill, 1969; Schrier et al., 1970), but the implications this holds for cardiovascular function at low body temperatures are unclear.

Here we have studied the influence of acute changes in body temperature on haematological parameters likely to alter the rheological properties

*Present address: Department of Zoology, University of California, Los Angeles, California, U.S.A. of the blood of a heliothermic lizard, Egernia cunninghami. A comparison is made with changes in these parameters occurring during torpor in the whitefooted mouse, Peromyscus leucopus. This mouse may undergo daily torpor in nature, and in the laboratory when food is rationed (Gaertner et al., 1973).

\section{MATERIALS AND METHODS}

Lizards were collected at Molesworth, Victoria, Australia, during February and May 1972. They were housed in a large herbarium equipped with heat lamps (photoperiod, 10L : 14D) and were fed lettuce, tomato and ox liver. Mice were obtained by live-trapping near Ann Arbor, Michigan, during February 1973, and as second generation off-spring of mice trapped the previous summer. They were housed separately, and fed initially Purina laboratory chow (23\% protein and $4.5 \%$ fat) ad lib. These mice were maintained in the laboratory at room temperature for at least 2 weeks prior to commencement of the experiments, and then transferred to a $14^{\circ} \mathrm{C}$ constant-temperature room (photoperiod, 13L : 11D).

Blood samples were drawn from the orbital sinus directly into $75 \mu \mathrm{l}$ capacity heparinized haematocrit tubes (Maclean et al., 1973). Haematocrits were measured after centrifuging duplicate samples for $3 \mathrm{~min}$ at 12,500 $\mathrm{rev} / \mathrm{min}$ (lizard blood) or for $20 \mathrm{~min}$ at $3500 \mathrm{rev} / \mathrm{min}$ (mouse blood). Haemoglobin concentration was measured by the cyanmethaemoglobin method as described in Maclean \& Lee (1973), using either a Shimadzu (lizard blood) or a Coleman Junior (mouse blood) spectrophotometer to measure optical density. The mean corpuscular haemoglobin concentration (MCHC) was calculated from the formula:

$$
\text { MCHC }=\frac{\text { haemoglobin concentration }}{\text { haematocrit }} \times 100 \text {. }
$$


This parameter gives a measure of the mean haemoglobin content of the red cells. Red cell counts were determined using a haemocytometer with Hayem's solution as the diluting medium. Total protein concentration of the plasma was measured with a Hitachi Type PRP-B refractometer.

\section{Effect of body temperature on plasma volume}

Samples of fifteen and thirteen lizards were placed in constant temperature rooms at 32.0 and $8.0^{\circ} \mathrm{C}$, respectively, and held there until body and ambient temperatures coincided. These temperatures were chosen because the preferred body temperature of this species is approximately $32.0^{\circ} \mathrm{C}$ (Wilson, 1972), and ambient temperatures in the animal's natural habitat often fall to $8.0^{\circ} \mathrm{C}$ or lower during a large part of the year (Berwick \& Bryant, 1966). Plasma volume was determined by the dilution of Evans blue dye ( $\mathrm{T}-1824)$ prepared in reptilian Ringer's solution. The lizards were weighed to the nearest $0 \cdot 1 \mathrm{~g}$ and anaesthetized with an intraperitoneal injection of $40 \mathrm{mg}$ sodium pentobarbitone (nembutal) per kg. The heart was exposed by opening the thorax, and the haematocrit determined on a 75- $\mu$ I sample of blood taken from the orbital sinus. A volume of $300 \mu \mathrm{l}$ of a $0.836 \%$ solution of the dye was then injected directly into the ventricle, and the animal placed in an atmosphere saturated with water vapour for the remainder of the experiment. Four 75- $\mu$ l blood samples were withdrawn from the orbital sinus at intervals of $20 \mathrm{~min}$ (for determinations at $32.0^{\circ} \mathrm{C}$ ) or $30 \mathrm{~min}$ (for determinations at $8.0^{\circ} \mathrm{C}$ ) from the time of injection. Quantities of $25 \mu \mathrm{l}$ of plasma from each of these samples were added to $3.0 \mathrm{ml}$ of water, and the optical densities read at $620 \mathrm{~nm}$ on the Shimadzu spectrophotometer. Optical densities were plotted against time, and the theoretical optical density of the plasma at the time of injection was obtained by extrapolating back to zero time. This figure was used when calculating plasma volume by comparison with standard solutions of Evans blue prepared in water. A sample of $25 \mu \mathrm{l}$ of plasma was added to each $3.0 \mathrm{ml}$ of standard solution.

\section{Effect of body temperature on haematological parameters}

This experiment was designed to ascertain the effect of acute changes in body temperature on blood parameters. Two samples of eight lizards were maintained overnight at an ambient temperature of $20.0^{\circ} \mathrm{C}$. The following morning one sample was kept at $20.0^{\circ} \mathrm{C}$, and the other placed in a large herbarium equipped with heat lamps at one end. After $90 \mathrm{~min}$, when the body temperatures of lizards in the second sample lay within the range $31-33^{\circ} \mathrm{C}$, these animals were placed in a constant temperature room at $32 \cdot 0^{\circ} \mathrm{C}$. Water was available at all times. Blood samples were then taken from both groups of lizards for the measurement of haemoglobin concentration, haematocrit and plasma protein concentration.

A second experiment was designed to investigate the effects of the diurnal changes in body temperature which the lizards may experience naturally. A group of nine lizards was provided with heat lamps at 0900 hours. After $2 \mathrm{hr}$ the animals were placed in a humidified atmosphere in a constant temperature chamber at $32.0^{\circ} \mathrm{C}$. At 1200 hours each animal was weighed to the nearest $0.1 \mathrm{~g}$, the body temperature measured and a sample of $250 \mu \mathrm{l}$ of blood withdrawn for the determination of haemoglobin concentration, haematocrit and plasma protein concentration. The ambient temperature was then lowered to $8.0^{\circ} \mathrm{C}$ at a rate of $3^{\circ} \mathrm{C} / \mathrm{hr}$. A second blood sample was withdrawn from each animal, and the body temperature measured, at 0500 hours the following morning. The ambient temperature was then raised to $32.0^{\circ} \mathrm{C}$ at a rate of $6^{\circ} \mathrm{C} / \mathrm{hr}$. Body temperatures were measured, and blood samples taken for the third time at 1200 hours. A control group of eight lizards was similarly treated, but maintained continuously at $32 \cdot 0^{\circ} \mathrm{C}$.

\section{Viscosity determinations}

Blood samples for determination of specific viscosity were withdrawn from a group of twenty-five lizards. The haematocrits of these samples ranged from 10 to 31 per cent. Plasma was used for 0 per cent haematocrit. Viscosity was measured at three different temperatures $\left(8 \cdot 0,20 \cdot 0\right.$ and $\left.32 \cdot 0^{\circ} \mathrm{C}\right)$ with a micro-capillary viscometer as modified by Lidstone (1952). Characteristics of the viscometer were: diameter of capillary $0.5 \mathrm{~mm}$, length of capillary $12 \mathrm{~cm}$, capacity $0.1 \mathrm{ml}$, and flow times for distilled water of $16.2 \mathrm{sec}$ at $8.0^{\circ} \mathrm{C}, 12.5 \mathrm{sec}$ at $20.0^{\circ} \mathrm{C}$ and $9.6 \mathrm{sec}$ at $32.0^{\circ} \mathrm{C}$. Specific viscosity was calculated from the formula:

$$
\eta_{T}=t \mathrm{sg} K_{T}
$$

where $\eta_{T}$ is the specific viscosity at temperature $T^{\circ} \mathrm{C}, t$ is the flow time in seconds, sg is the specific gravity and $K_{T}$ is the calibration constant of the viscometer at temperature $T^{\circ} \mathrm{C}$. Flow time was taken as the mean of five measurements. Specific gravity of blood and plasma samples was determined by the copper sulphate method of Phillips et al. (1950). Calibration constants, calculated from the formula:

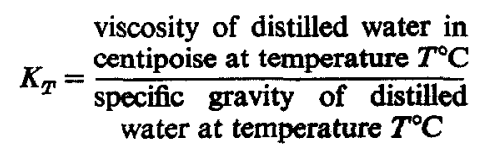

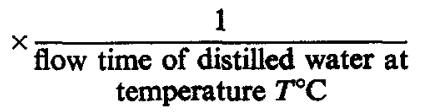

were $K_{8.0}=0.085, K_{20.0}=0.080$ and $K_{32.0}=0.080$.

Since the viscosity of distilled water at $20.0^{\circ} \mathrm{C}$ is 1.00 centipose (Weast, 1970), specific viscosities are expressed relative to the viscosity of water at this temperature.* Temperatures of the blood samples were controlled by immersion of the viscometer in a water-bath, and all measurements were conducted in constant temperature rooms maintained at the test temperature.

\section{Effect of diurnal torpor on haematological parameters}

The mice were weighed daily to the nearest $0.1 \mathrm{~g}$, and rectal temperatures measured with a YSI telethermometer. The thermistor was inserted at least $3 \mathrm{~cm}$

*Capillary viscometers slightly overestimate relative viscosity at low temperatures (Barbee, 1973). Nevertheless these inherent errors are small when compared with the temperature-dependent increases we obtained. 


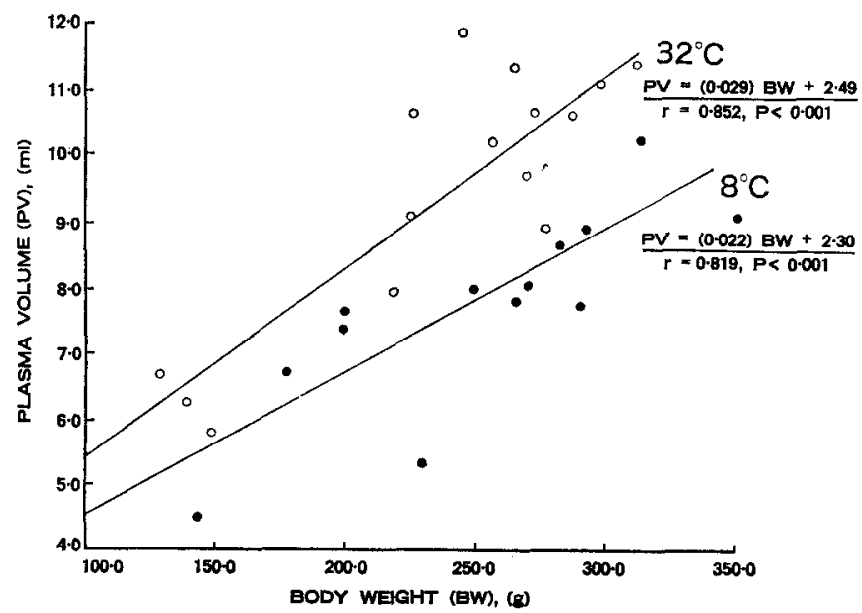

Fig. 1. Relationship between plasma volume and body weight in $E$. cunninghami at body temperatures of $32^{\circ} \mathrm{C}(0)$ and $8^{\circ} \mathrm{C}(\bullet)$.

into the rectum before temperatures were recorded. Both experimental and control animals were maintained on a restricted food ration consisting of $0.5-1.5 \mathrm{~g}$ sunflower seeds per day. The exact amount of food given was adjusted so that torpor was induced with a minimum weight loss.

Samples of $150 \mu \mathrm{l}$ of blood were withdrawn from the experimental animals during torpor. Each sample was obtained within $10 \mathrm{sec}$ after disturbing the animal. A second blood sample was taken approximately $12 \mathrm{hr}$ later when the animal was active. Body temperatures were recorded immediately after each bleeding. The control group was treated similariy, except that both blood samples were obtained while the animals were active. The blood was used for determination of haemoglobin concentration, haematocrit and red cell counts.

\section{RESULTS}

The mean circulating plasma volume of lizards at a body temperature of $8^{\circ} \mathrm{C}$ was 18.7 per cent lower than at a body temperature of $32^{\circ} \mathrm{C}$ (Table 1). The

Table 1. Circulating plasma volume in the lizard E. cunninghami at two body temperatures

\begin{tabular}{|c|c|}
\hline & Body temperature \\
\hline & $8.0-8.8^{\circ} \mathrm{C} \quad 31.8-32.6^{\circ} \mathrm{C}$ \\
\hline & $\underset{(N)}{\operatorname{mean} \pm \text { S.E. }} \underset{(N)}{\operatorname{mean} \pm \text { S.E. }}$ \\
\hline \multirow[t]{2}{*}{ Plasma volume $(\mathrm{ml})$} & $\begin{array}{cc}7.70 \pm 0.43 & 9.47 \pm 0.51 \\
(13) & (15)\end{array}$ \\
\hline & $P<0.01$ \\
\hline Body weight (g) & $\begin{array}{cc}250 \cdot 5 \pm 16 \cdot 9 & 238 \cdot 4 \pm 15 \cdot 4 \\
(13) & (15)\end{array}$ \\
\hline
\end{tabular}

equations relating plasma volume $(\mathrm{PV}, \mathrm{ml})$ to body weight (BW, g) at these temperatures (Fig. 1) are:

$$
\begin{gathered}
\mathrm{PV}=(0.029) \mathrm{BW}+2.49 \\
(r=0.852, N=15, P<0.001) \text { at } 32^{\circ} \mathrm{C} \\
\mathrm{PV}=(0.022) \mathrm{BW}+2.30 \\
\quad(r=0.819, N=13, P<0.001) \text { at } 8^{\circ} \mathrm{C}
\end{gathered}
$$

\begin{tabular}{|c|c|c|}
\hline & \multicolumn{2}{|c|}{ Body temperature } \\
\hline & \multicolumn{2}{|c|}{$20 \cdot 0-20 \cdot 6^{\circ} \mathrm{C} \quad 31 \cdot 2-32.6^{\circ} \mathrm{C}$} \\
\hline & \multicolumn{2}{|c|}{$\underset{(N)}{\operatorname{Mean} \pm \text { S.E. }} \underset{(N)}{\text { Mean } \pm \text { S.E. }}$} \\
\hline \multirow[t]{2}{*}{ Specific viscosity } & $\begin{array}{c}2.84 \pm 0.09 \\
(8)\end{array}$ & $2 \cdot 60 \pm 0 \cdot 16$ \\
\hline & \multicolumn{2}{|c|}{ N.S. } \\
\hline \multirow[t]{2}{*}{ Haematocrit $(\%)$} & $\frac{18 \cdot 2 \pm 0.97}{(8)}$ & $\frac{23 \cdot 4 \pm 1}{(7)}$ \\
\hline & \multicolumn{2}{|c|}{$P<0.01$} \\
\hline $\begin{array}{l}\text { Haemoglobin } \\
\text { concentration } \\
(\mathrm{g} / 100 \mathrm{ml} \text { blood })\end{array}$ & $\begin{array}{c}5 \cdot 78 \pm 0 \cdot 41 \\
(8) \quad P<\end{array}$ & $\underset{(7)}{7 \cdot 61 \pm 0.28}$ \\
\hline $\begin{array}{l}\text { Mean corpuscular } \\
\text { haemoglobin } \\
\text { concentration } \\
\text { (g/100 ml red cells) }\end{array}$ & \multicolumn{2}{|c|}{ N.S. } \\
\hline \multirow[t]{2}{*}{$\begin{array}{l}\text { Plasma protein } \\
\text { concentration }(\%)\end{array}$} & $\begin{array}{c}8 \cdot 8 \pm 0.98 \\
(8)\end{array}$ & $\begin{array}{c}6.5 \pm 0.46 \\
(7)\end{array}$ \\
\hline & \multicolumn{2}{|c|}{$P<0.05$} \\
\hline Body weight (g) & $\begin{array}{r}251 \cdot 3 \pm 24 \cdot 1 \\
(8) \quad \mathrm{N}\end{array}$ & $\begin{array}{l}227 \cdot 4 \pm 27 \cdot 7 \\
\text { S. }\end{array}$ \\
\hline
\end{tabular}

Table 2. Relation of some blood parameters to body temperature in the lizard $E$. cunninghami

The effects of acute changes in body temperature of the lizards is shown in Tables 2 and 3. At $20^{\circ} \mathrm{C}$ the mean haematocrit was 22.3 per cent lower, 
Table 3. Variations in haematocrit, haemoglobin concentration and plasma protein concentration associated with experimentally induced diurnal changes in body temperature in the lizard E. cunninghami

\begin{tabular}{|c|c|c|c|c|}
\hline & & $\begin{array}{l}\text { First } \\
\text { Bleeding } \\
(0 \mathrm{hr})\end{array}$ & $\begin{array}{l}\text { Second } \\
\text { Bleeding } \\
(17 \mathrm{hr})\end{array}$ & $\begin{array}{l}\text { Third } \\
\text { Bleeding } \\
(24 \mathrm{hr})\end{array}$ \\
\hline Body temperature $\left({ }^{\circ} \mathrm{C}\right)$ & $\begin{array}{l}\text { Controls (8) } \\
\text { Experimentals (9) }\end{array}$ & $\begin{array}{l}31 \cdot 8-32 \cdot 4 \\
31 \cdot 8-32 \cdot 5\end{array}$ & $\begin{array}{c}32 \cdot 0-32 \cdot 4 \\
8 \cdot 0-8 \cdot 6\end{array}$ & $\begin{array}{l}32 \cdot 0-32 \cdot 2 \\
32 \cdot 0-32 \cdot 4\end{array}$ \\
\hline $\begin{array}{c}\text { Haematocrit }(\%) \\
(\text { mean } \pm \text { S.E. })\end{array}$ & $\begin{array}{l}\text { Controls (8) } \\
\text { Experimentals (9) }\end{array}$ & $\begin{array}{l}27 \cdot 8 \pm 1 \cdot 02 \\
27 \cdot 7 \pm 0 \cdot 86 \\
\text { N.S. }\end{array}$ & $\begin{array}{c}24 \cdot 7 \pm 1.07 \\
21 \cdot 2 \pm 0.85 \\
P<0.05\end{array}$ & $\begin{array}{l}23 \cdot 2 \pm 1 \cdot 49 \\
23 \cdot 1 \pm 0 \cdot 98 \\
\text { N.S. }\end{array}$ \\
\hline $\begin{array}{l}\text { Haemoglobin } \\
\text { concentration } \\
\text { (g/100 ml blood) } \\
\text { (mean } \pm \text { S.E.) }\end{array}$ & $\begin{array}{l}\text { Controls (8) } \\
\text { Experimentals (9) }\end{array}$ & $\begin{array}{l}7 \cdot 7 \pm 0 \cdot 50 \\
7 \cdot 5 \pm 0 \cdot 31 \\
\text { N.S. }\end{array}$ & $\begin{array}{l}6.9 \pm 0.44 \\
5.8 \pm 0.29 \\
P<0.05\end{array}$ & $\begin{array}{c}6 \cdot 2 \pm 0 \cdot 42 \\
6 \cdot 3 \pm 0 \cdot 22 \\
\text { N.S. }\end{array}$ \\
\hline $\begin{array}{l}\text { Plasma protcin } \\
\text { concentration }(\%) \\
\text { (mean } \pm \text { S.E.) }\end{array}$ & $\begin{array}{l}\text { Controls (8) } \\
\text { Experimentals (9) }\end{array}$ & $\begin{array}{l}6 \cdot 6 \pm 0 \cdot 34 \\
6 \cdot 2 \pm 0 \cdot 38 \\
\text { N.S. }\end{array}$ & $\begin{array}{l}6.2 \pm 0.33 \\
6.0 \pm 0.39 \\
\text { N.S. }\end{array}$ & $\begin{array}{l}6 \cdot 0 \pm 0 \cdot 30 \\
6 \cdot 0 \pm 0 \cdot 33 \\
\text { N.S. }\end{array}$ \\
\hline
\end{tabular}

and the haemoglobin concentration 24.0 per cent lower, than at $32^{\circ} \mathrm{C}$. As a consequence of the lowered haematocrit, the mean in vitro specific viscosity of blood at $20^{\circ} \mathrm{C}$ did not differ significantly from the value at $32^{\circ} \mathrm{C}$. The dependence of viscosity on haematocrit and temperature is illustrated in Fig. 2. After the body temperature was lowered from 32 to $8^{\circ} \mathrm{C}$, mean haematocrit and haemoglobin concentration were significantly lower than the mean values for controls held at $32^{\circ} \mathrm{C}$ (Table 3). However, when the body temperature was increased again to $32^{\circ} \mathrm{C}$, the mean haematocrit and haemoglobin concentration returned the levels in the controls. This procedure of serially sampling blood from these lizards progressively lowered the haematocrit and haemoglobin concentration in the controls.

Many of the mice maintained on the restricted diet became torpid after 5-16 days, and re-entered torpor daily. Some animals, however, did not enter torpor but died after continued food rationing.

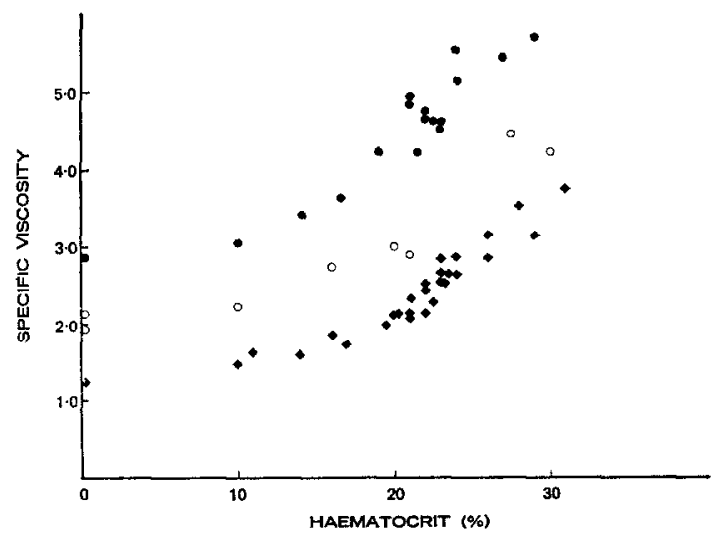

Fig. 2. Relationship between specific viscosity and haematocrit of the blood of $E$. cunninghami at temperatures of $32^{\circ} \mathrm{C}(\diamond), 20^{\circ} \mathrm{C}(0)$ and $8^{\circ} \mathrm{C}(\bullet)$.
Results from these animals were discarded. The initial body weights of the samples were 18.9 \pm $0.79 \mathrm{~g}$ for the experimental group and $19.0 \pm 0.69 \mathrm{~g}$ for the controls. Upon entry into torpor the mean body weights were reduced to $80 \cdot 1$ and 75.7 per cent of the initial weights respectively. Body weights of the experimental and control groups did not differ significantly.

The mean body temperature of torpid animals fell from 37.4 to $21.9^{\circ} \mathrm{C}$. The results of haematological measurements on these mice are presented in Table 4. In contrast to the lizards, these animals showed no significant changes in any of the blood parameters during torpor.

\section{DISCUSSION}

Lowering the body temperature of the lizard $E$. cunninghami induced a significant reduction in circulating plasma volume. This response has been observed in other reptiles (Huggins, 1961; Semple, 1964; Stitt et al., 1970), and probably results from widespread peripheral vasoconstriction. In turtles exposed to cold, Stitt \& Semple (1971) and Stitt et al. (1971) found a sequestration of plasma in blood vessels closed to the general circulation. This plasma returned to the circulation upon re-warming the animal.

Our results indicate that substantial parallel reductions in haematocrit and haemoglobin concentration also occur as the body temperature of the lizard is lowered. In view of the reduced plasma volume, this haemodilution must have resulted from a reduction in the number of circulatng red cells. This change in red cell distribution was acutely reversible when body temperatures were increased to the control level. Similar adjustments may occur in other reptiles. For example, Musacchia \& Sievers (1956) reported haemodilution in the turtle, Chrysemys picta, following exposure to an ambient temperature of $0^{\circ} \mathrm{C}$ for 1 week, and concluded that 
Table 4. Variations in haematocrit, haemoglobin concentration, mean corpuscular haemoglobin concentration and red cell count, associated with fasting-induced diurnal torpor in the whitefooted mouse, $P$. leucopus

\begin{tabular}{|c|c|c|c|}
\hline & & $\begin{array}{l}\text { First bleeding } \\
\qquad(0 \mathrm{hr})\end{array}$ & $\begin{array}{l}\text { Second bleeding } \\
(12 \mathrm{hr})\end{array}$ \\
\hline $\begin{array}{l}\text { Body Temperature }\left({ }^{\circ} \mathrm{C}\right) \\
(\text { mean } \pm \text { S.E. })(N)\end{array}$ & $\begin{array}{l}\text { Controls } \\
\text { Experimentals }\end{array}$ & $\begin{array}{l}37 \cdot 4 \pm 0 \cdot 25(8) \\
21 \cdot 9 \pm 1 \cdot 15(11)\end{array}$ & $\begin{array}{l}37 \cdot 3 \pm 0 \cdot 29(8) \\
36 \cdot 9 \pm 0 \cdot 19(9)\end{array}$ \\
\hline $\begin{array}{l}\text { Haematocrit }(\%) \\
\quad(\text { mean } \pm \text { S.E. })(N)\end{array}$ & $\begin{array}{l}\text { Controls } \\
\text { Experimentals }\end{array}$ & $\begin{array}{c}55.0 \pm 1.32(8) \\
56 \cdot 1 \pm 0.88(11) \\
\text { N.S. }\end{array}$ & $\begin{array}{c}46.9+0.83(8) \\
48.9 \pm 1.25(9) \\
\text { N.S. }\end{array}$ \\
\hline $\begin{array}{l}\text { Haemoglobin } \\
\text { concentration } \\
(\mathrm{g} / 100 \mathrm{ml} \text { blood) } \\
(\text { mean } \pm \text { S.E. })(N)\end{array}$ & $\begin{array}{l}\text { Controls } \\
\text { Experimentals }\end{array}$ & $\begin{array}{c}17 \cdot 2 \pm 0.39(8) \\
17 \cdot 8 \pm 0.22(11) \\
\text { N.S. }\end{array}$ & $\begin{array}{c}15 \cdot 0 \pm 0 \cdot 30(8) \\
15 \cdot 4 \pm 0 \cdot 37(9) \\
\text { N.S. }\end{array}$ \\
\hline $\begin{array}{l}\text { Mean corpuscular } \\
\text { haemoglobin } \\
\text { concentration } \\
\text { (g/100 ml red cells) } \\
\text { (mean } \pm \text { S.E.) }(N)\end{array}$ & $\begin{array}{l}\text { Controls } \\
\text { Experimentals }\end{array}$ & $\begin{array}{c}31 \cdot 3 \pm 0.94(8) \\
31 \cdot 7 \pm 1 \cdot 59(11) \\
\text { N.S. }\end{array}$ & $\begin{array}{c}32 \cdot 0 \pm 0.96(8) \\
31 \cdot 4 \pm 0.60(9) \\
\text { N.S. }\end{array}$ \\
\hline $\begin{array}{l}\text { Mean red cell count } \\
\left(\text { cells } / \mathrm{mm}^{3} \text { blood }\right. \\
\left.\times 10^{6}\right) \\
(\text { mean } \pm \text { S.E. })(N)\end{array}$ & $\begin{array}{l}\text { Controls } \\
\text { Experimentals }\end{array}$ & $\begin{array}{c}13 \cdot 7 \pm 0 \cdot 51(8) \\
12 \cdot 9 \pm 0 \cdot 25(11) \\
\text { N.S. }\end{array}$ & $\begin{array}{c}11 \cdot 5 \pm 0.38(8) \\
11 \cdot 0 \pm 0 \cdot 28(9) \\
\text { N.S. }\end{array}$ \\
\hline
\end{tabular}

this was the consequence of corpuscles leaving the circulating blood. Similarly, Huggins \& Percoco (1965) reported a reduced red cell volume and venous circulating haematocrit in the American alligator (Alligator mississippiensis) exposed to cold $\left(3-4^{\circ} \mathrm{C}\right)$ for $24 \mathrm{hr}$. It appears, therefore, that sequestration of red cells in parts of the vascular system closed to the general circulation is a common response in reptiles following a reduction in body temperature. The sites of sequestration are unknown, but the spleen may play an important role. Huggins \& Percoco (1965) reported a substantial increase in the red cell volume of the spleen of alligators during exposure to cold.

E. cunninghami is a heliothermic lizard which may experience large diurnal changes in body temperature (Barwick, 1965; Wilson \& Lee, 1974). The substantial alteration in red cell distribution associated with these temperature changes may have important consequences for the functioning of the cardiovascular system, and its potential for oxygen transport. The rate of oxygen delivery to the tissues is a function of both the oxygen capacity of the blood and the rate of blood flow. The oxygen capacity is generally increased when the haematocrit ratio is increased (Larimer, 1959). However, this also increases blood viscosity which tends to reduce flow rate (Schrier et al., 1970). Similarly, a decrease in hacmatocrit ratio reduces the oxygen capacity but tends to increase flow rate. Consequently, under a given set of conditions, an optimal haematocrit cxists at which the potential for oxygen transport is maximal (Murray et al., 1962; Castle \& Jandl, 1966; Snyder, 1971). Several investigators have calculated values for optimal haematocrits on blood from a number of mammalian species (Crowell \& Smith, 1967; Stone et al., 1968), and from the lizard Dipsosaurus dorsalis (Snyder, 1971). In general, a close similarity exists between the observed haematocrit values and the calculated optimal haematocrits.

The optimal haematocrit can be altered under certain conditions. In many mammals, for example, the observed haematocrit has been found to increase after acclimation to high altitude (Anthony \& Krieder, 1961), or cold (Maclean \& Lee, 1973). In these cases, however, the increased haematocrit is accompanied by an increased total blood volume, and the resistance to blood flow is reduced such that the calculated value for optimal haematocrit is increased (Castle \& Jandl, 1966). Snyder's (1971) finding that the optimal haematocrit is also temperature dependent is of particular significance. At low temperatures the tendency towards increased viscosity and reduced flow rates lowers the calculated value for optimal haematocrit. Snyder suggested that, in some poikilothermic and heterothermic animals, reduced haematocrits may represent temperature-induced cardiovascular adjustments which maximize the potential for systemic oxygen transport during hypothermia. Our findings for E. cunninghami are consistent with this view. Indeed, our data suggest little change in blood viscosity between body temperatures of $20^{\circ} \mathrm{C}$ and the preferred body temperature of $32^{\circ} \mathrm{C}$. Because whole blood is a non-Newtonian fluid, its viscosity increases significantly as the velocity of flow decreases, such that the viscosity in the microcirculation may be several times greater than in the large arteries (Wells, 1964). Consequently, caution 
is necessary in translating, in quantitative terms, in vitro measurements obtained with capillary viscometers, to the vascular bed. Nevertheless, our comparative viscosity measurements are useful in indicating that the cardiovascular system of $E$. cunninghami possesses a mechanism for rendering blood viscosity relatively temperature-independent over a certain range of body temperatures.

Quite apart from the influence of temperatureinduced viscosity increases on tissue perfusion, is the mutually reinforcing problem of intravascular aggregation or red thrombus formation. Dintenfass (1963) showed that red thrombi form in blood at low velocity, and once formed these are protected by the yield sheer stress of the blood, since a finite force is required to shift a thrombus (Merrill, 1969). Hence the slow or "stop-start" flow of the venous system is conducive to thrombus formation, particularly if viscosity is increased at low temperatures. There is, however, evidence of increased coagulation time and anticoagulant titre in the blood of hypothermic reptiles (Jacques \& Mussachia, 1961 ; Jacques, 1963; Zain-ul-abedin \& Katorski, 1967), and this solution may contribute more to maintaining haemofluidity during periods of hypothermia than compensation for viscosity per se.

Snyder (1971) suggested that a reduction in the number of erythrocytes in the blood may also occur in mammals entering hibernation, and cited instances of haemodilution in hibernating ground squirrels (Popovic, 1964) and torpid bats (Lidicker \& Davis, 1955). However, a review of the literature concerning the haematological responses of hibernating mammals does not fully support Snyder's view. Haematological data from hibernating mammals are conflicting (Table 5). For example, Svibla et al. (1952), Hock (1964) and Nansel \& Knoche (1972) obtained an increase in haematocrit, Kallen (1961) observed no change and Popovic (1964) and Galster \& Morrison (1966) observed a decrease in haematocrit. Certain of these differences may represent specific differences in response, although other factors may contribute. First, a reduction in erythropoiesis may occur during hibernation (Brock, 1960), so that haematocrits measured after a period of hibernation may reflect chronic changes in erythropoiesis rather than an acute alteration in red cell distribution. Consequently, it is important to distinguish between comparisons made before and during hibernation with comparisons made during and after hibernation. Second, differences in technique may also be important. For example, Nansel \& Knoche (1972) found that torpid ground squirrels showed an increased haematocrit but no change in haemoglobin concentration or red cell count. The increased haematocrit apparently

Table 5. Adjustments in haematocrit and red cell counts during torpor in mammals

\begin{tabular}{|c|c|c|c|c|}
\hline Species & Active & Torpid & Difference & Reference \\
\hline \multicolumn{5}{|l|}{ Haematocrit } \\
\hline Peromyscus leucopus & $55 \cdot 0$ & $56 \cdot 1$ & 0 & This study \\
\hline Citellus undulatus & $31 \cdot 9$ & $42 \cdot 2$ & + & Hock (1964) \\
\hline C. undulatus & $37 \cdot 3$ & $50 \cdot 2$ & + & Svihla et al. (1952) \\
\hline Citellus tridecemlineatus & 57 & 40 & - & Popovic (1964) \\
\hline C. tridecemlineatus & $46 \cdot 8$ & $48 \cdot 2$ & + & Riedesel \& Folk (1958) \\
\hline C. tridecemlineatus & - & - & - & Galster \& Morrison (1966) \\
\hline Marmota monax & - & - & 0 & Wenberg et al. (1973) \\
\hline M. $\operatorname{monax}$ & $31 \cdot 4$ & $48 \cdot 8$ & + & McBirnie et al. (1953) \\
\hline Spermophilus columbianus & $45 \cdot 5$ & $53 \cdot 5$ & + & Nansel \& Knoche (1972) \\
\hline Myotis lucifugus & - & - & 0 & Kallen (1961) \\
\hline Myotis sodalis & - & - & - & Lidicker \& Davis (1955) \\
\hline Cricetus cricetus & $40 \cdot 0$ & $55 \cdot 5$ & + & Lyman \& Chatfield (1955) \\
\hline Erinaceus europaeus & 45 & 35 & - & Biörck et al. (1956) \\
\hline E. europaeus & $47 \cdot 0$ & $33 \cdot 2$ & - & Bartels et al. (1969) \\
\hline \multicolumn{5}{|l|}{ Red blood cell count $\times 10^{6}$} \\
\hline Peromyscus leucopus & $13 \cdot 7$ & $12 \cdot 9$ & 0 & This study \\
\hline Citellus undulatus & $5 \cdot 9$ & $8 \cdot 0$ & + & Hock (1964) \\
\hline C. undulatus & $7 \cdot 1$ & $9 \cdot 0$ & + & Svihla et al. (1952) \\
\hline Citellus tridecemlineatus & $8 \cdot 1$ & 5.0 & - & Stuckey \& Coco (1942) \\
\hline Spermophilus columbianus & $10 \cdot 6$ & $10 \cdot 6$ & 0 & Nansel \& Knoche (1972) \\
\hline Marmota monax & - & - & 0 & Wenberg et al. (1973) \\
\hline$M . \operatorname{monax}$ & 6.2 & 6.6 & 0 & Rasmussen (1916) \\
\hline$M . \operatorname{monax}$ & $4 \cdot 8$ & $5 \cdot 3$ & + & Dubois (1896) \\
\hline Cricetus cricetus & $7 \cdot 7$ & $8 \cdot 2$ & + & Raths (1953) \\
\hline C. cricetus & $8 \cdot 0$ & 9.8 & + & Lyman \& Chatfield (1955) \\
\hline Erinaceus europaeus & $9 \cdot 0$ & $7 \cdot 4$ & - & Biörck et al. (1956) \\
\hline E. europaeus & $8 \cdot 6$ & $7 \cdot 7$ & - & Bartels et al. (1969) \\
\hline
\end{tabular}


resulted from measurements made while the blood was cold. Our studies on blood changes during torpor in $P$. leucopus were designed to avoid these problems.

The daily pattern of body temperatures of these mice resembles more closely the pattern in heliothermic lizards than hibernating mammals. In addition, our experimental design and blood analysis techniques were very similar to those used for our lizard study. Our results indicate that the response of the blood system of the mouse during torpor is different from that of the lizard during hypothermia, since there were no significant changes in haematocrit, haemoglobin concentration or red cell count. Therefore, haemodilution is not an invariable response during torpor in mammals.

Heterothermic mammals, like reptiles, show prolonged clotting time during torpor, and this is associated with a decreased prothrombin titre (Soumalainen \& Lehto, 1952; Svihla et al., 1952; Smith et al., 1954; Biörck et al., 1962). Artificially induced hypothermia in homeothermic mammals is generally accompanied by an increase in haematocrit and consequently blood viscosity, caused in part, by splenic contraction (Kanter, 1968). Apparently the spleen did not contract during torpor in $P$. leucopus since there was no change in haematocrit. Besides adjustments reducing the tendency for intravascular aggregation, these mammals appear to have mechanisms other than haemodilution which compensate for increased viscosity. Recently, for instance, Halikas \& Bowers (1973) observed that the viscosity of the blood of Arctic ground squirrels is less temperature-dependent than that of humans. The basis for this difference may lie in the inherent structural properties of the red blood cell membranes affecting properties such as deformability or shape (Chien et al., 1971).

\section{SUMMARY}

The lizard, E. cunninghami, showed reversible changes in haematocrit, haemoglobin concentration and blood volume which were related to body temperature. These changes are consistent with other observations on reptiles. Reductions in haematocrit with body temperature preclude changes in blood viscosity, and appear to maximize the potential for systemic oxygen transport and minimize the propensity for intravascular aggregation during hypothemia.

On the other hand, no consistent relationship has emerged between haematocrit or red blood cell count and body temperature in hibernating mammals. In the mouse, $\boldsymbol{P}$. leucopus, haematocrit and red blood cell count did not alter during bouts of daily torpor. Other cardiovascular adjustments presumably preclude or compensate for increases in blood viscosity and the propensity for intravascular aggregation during torpor.
Acknowledgements-We thank Dr. W. R. Dawson for his assistance and advice, Miss C. Carey and Mr. R. Marsh for critically reading the manuscript and Jane Lee for preparing the figures.

\section{REFERENCES}

Alpert N. R., Sommer J. R., Hartshorne D. J., Dreizen P., Sleator W. W. \& Hawthorne E. W. (1972) Excitation and contraction mechanisms in heart muscle during hibernation and hypothermia. In Hibernation and Hypothermia, Perspectives and Challenges (Edited by South F. E., HanNon J. P., Willis J. R., Pengelley E. T. \& Alpert N. R.), pp. 481-484. Elsevier, Amsterdam.

ANTHONY A. \& KREIDER J. (1961) Blood volume changes in rodents exposed to simulated high altitude. $A m$.J. Physiol. 200, 523-526.

Barbee J. H. (1973) The effect of temperature on the relative viscosity of human blood. Biorheology 10, 1-5.

BarTels H., SCHMElzLe R. \& UlRICH S. (1969) Comparative studies of the respiratory function of mammalian blood-V. Insectivora: shrew, mole and nonhibernating and hibernating hedgehog. Resp. Physiol. 7, 278-286.

BARWICK R. E. (1965) Studies on the scincid lizard Egernia cunninghami (Gray 1832). Ph.D. thesis, Australian National University, Canberra.

Barwick R. E. \& BRyant C. (1966) Physiological and biochemical aspects of hibernation in the scincid lizard, Egernia cunninghami (Gray 1832). Physiol, Zoöl. 39, 1-20.

BiörcK G., Johansson B. \& Veigz S. (1956) Some laboratory data on hedgehogs, hibernating and nonhibernating. Acta physiol. scand. 37, 281-294.

Biörck G., Johansson B. W. \& NILsson I. M. (1962) Blood coagulation studies in hedgehogs, in a hibernating and a non-hibernating state, and in dogs, hypothermic and normothermic. Acta physiol. scand. 56, 334-348.

Brock M. A. (1960) Production and life span of erythrocytes during hibernation in the golden hamster. Am. J. Physiol. 198, 1181-1186.

Castle W. B. \& JandL J. H. (1966) Blood viscosity and blood volume: opposing influences upon oxygen transport in polycythemia. Seminars in Hematology 3, 193-198.

Chien S., Usami S., Dellenback R. J. \& Bryant C. A. (1971) Comparative hemorheology-hematological implications of species differences in blood viscosity. Biorheology 8, 35-57.

Crowell J. W. \& SMTtH E. E. (1967) Determinant of the optimal hematocrit. J. appl. Physiol. 22, 501-504.

DinTENFAss L. (1963) A study in rheology of blood clotting in human subjects. In Proceedings of the Fourth International Congress on Rheology 4. Symposium on Biorheology (Edited by CopleY A. F.), pp. 593-600.

Dubors R. (1896) Physiologie comparee de la marmotte. Ann. Univ. Lyon. 1896, 1-268.

GaERTNER R. A., HaRT J. S. \& Roy O. Z. (1973) Seasonal spontaneous torpor in the white-footed mouse, Peromyscus leucopus. Comp. Biochem. Physiol. 45A, 169-181.

GAISTER W. A. \& MorRison P. (1966) Seasonal changes in serum lipids and proteins in the 13-lined ground squirrel. Comp. Biochem. Physiol. 18, 489-501. 
Halikas G. \& Bowers K. (1973) Seasonal variation in blood viscosity of the hibernating Arctic ground squirrel (Spermophilus undulatus plesius). Comp. Biochem. Physiol. 44A, 677-681.

Hock R. J. (1964) Relative viscosity and other functions of the blood of hibernating and active Arctic ground squirrels. Ann. Acad. Sci. Fenn. Ser. A. IV. Biol. 71, 186-198.

Hudson J. W. (1973) Torpidity in mammals. In Comparative Physiology of Temperature Regulation (Edited by WhITTOw G. C.), Vol. 3, pp. 98-166. Academic Press, New York.

HugGins S. E. (1961) Blood volume parameters of a poikilothermal animal in hypo- and hyperthermia. Proc. Soc. exp. Biol. Med. 108, 231-234.

Huggins S. E. \& Percoco R. A. (1965) Blood volume in alligators during prolonged hypothermia. Proc. Soc. exp. Biol. Med. 119, 678-682.

JACQUES F. A. (1963) Blood coagulation and anticoagulant mechanisms in the turtle Pseudemys elegans. Comp. Biochem. Physiol. 9, 241-249.

JACQues F. A. \& MussaChIA X. J. (1961) Variations in concentrations of a metachromatic staining anticoagulant in plasma of the turtle, Pseudomys scripta elegans. Copeia 1961, 222-223.

JoHANSSON B. W. (1967) Heart and circulation in hibernators. In Mammalian Hibernation (Edited by FISHER K. C., Dawe A. R., Lyman C. P., Schonbaum E. \& South F. E.), Vol. III, pp. 200-218. Oliver \& Boyd, Edinburgh.

KALLEN F. C. (1961) Vascular changes related to hibernation in the vespertilionid bat Myotis lucifugus. Bull. Mus. Comp. zool. Harvard 124, 373-386.

KANTER G. S. (1968) Hypothermic hemoconcentration. Am. J. Physiol. 214, 856-859.

LARIMER J. L. (1959) Hemoglobin concentration and oxygen capacity of mammalian blood. J. Elisha Mitchell Sci. Soc. 75, 174-177.

Lidicker W. Z. \& Davis W. H. (1955) Changes in splenic weight associated with hibernation in bats. Proc. Soc. exp. Biol. Med. 89, 640-642.

LIDSTONE F. M. (1952) A micro viscometer of improved design. Chem. Ind. 1952, 873-874.

Lyman C. P. \& Chatfield P. O. (1955) Physiology of hibernation in mammals. Physiol. Rev. 35, 403 425.

McBirnie J. E., Pearson F. G., Trusler G. A., Karachi H. H. \& Bigelow W. G. (1953) Physiologic studies of the groundhog (Marmota monax). Can. J. Med. Sci. 31, 421-430.

Maclean G. S. \& Lee A. K. (1973) The effect of season, temperature, and activity on some blood parameters of feral house mice (Mus musculus). J. Mammal. 54, 660-667.

Maclean G. S., Lee A. K. \& Wilson K. J. (1973) A simple method of obtaining blood from lizards. Copeia 1973, 338-339.

Merrill E. W. (1969) Rheology of blood. Physiol. Rev 49, 863-888.

MurRay J. F., Gold P. \& Johnson B. L. (1962) Systemic oxygen transport in induced normovolemic anemia and polycythemia. Am. J. Physiol. 203, 720724.

Musacchia X. J. \& Sievers M. L. (1956) Effects of induced cold torpor on blood of Chrysemys picta. Am. J. Physiol. 187, 99-102.
Nansel D. \& Knoche L. (1972) Blood changes in torpid and non-torpid Columbian ground squirrels, Spermophilus columbianus. Comp. Biochem. Physiol. 41A, 175-179.

Phillips R. A., van Slyke D. D., Hamilton P. B., Dole V. P., Emerson K. \& Archibald R. M. (1950) Measurement of specific gravities of whole blood and plasma by standard copper sulfate solutions. J. biol. Chem. 183, 305-330.

Popovic V. (1964) Cardiac output in hibernating ground squirrels. Am. J. Physiol. 207, 1345-1348.

RASMussen A. T. (1916) The corpuscles, hemoglobin content and specific gravity of the blood during hibernation in the woodchuck (Marmota monax). Am. J. Physiol. 41, 464-482.

Raths P. (1953) Untersuchungen über die Blutzusammensetzung und ihre Beziehungen zur vegetativen Tonuslage beim Hamster (Cricetus cricetus L.). Z. Biol. 106, 109-123.

RIEDESEL M. L. \& FolK G. E. (1958) Serum electrolyte levels in hibernating mammals. Am. Nat. 92, 307312.

Schrier R. W., McDonald K. M., Wells R. E. \& LAULER D. P. (1970) Influence of hematocrit and colloid on whole blood viscosity during volume expansion. Am. J. Physiol. 218, 346-352.

SEMPLE R. E. (1964) Effects of temperature on blood and plasma volumes in the turtle. Physiologist 7, 251.

Smith D. E., Lewis Y. S. \& Svihla G. (1954) Prolongation of clotting time in the dormant bat (Myotis lucifugus). Experientia 10, 218.

SNYDER G. K. (1971) Influence of temperature and hematocrit on blood viscosity. Am. J. Physiol. 220, 1667-1672.

Soumalainen P. \& Lehto E. (1952) Prolongation of clotting time in the hibernating hedgehog. Arch. Soc. Zool. Bot. Fenn. Vanamo 6, 94-96.

StrTt J. T. \& Semple R. E. (1971) Sites of plasma sequestration induced by body cooling in turtles. Am. J. Physiol. 221, 1189-1191.

Stitt J. T., Semple R. E. \& Sigsworth D. W. (1970) Effect of changes in body temperature on circulating plasma volume of turtles. Am. J. Physiol. 219, 683686.

Stitt J. T., Semple R. E. \& Sigsworth D. W. (1971) Plasma sequestration produced by acute changes in body temperature in turtles. Am. J. Physiol. 221, 1185-1188.

Stone H. O., Thompson H. K. \& Schmidt-Nielsen K. (1968) Influence of erythrocytes on blood viscosity. Am. J. Physiol. 214, 913-918.

Stuckey J. \& Coco R. M. (1942) A comparison of the blood pictures of active and hibernating ground squirrels. Am. J. Physiol. 137, 431-435.

Svihla A., Bowman H. \& Pearson R. (1952) Prolongation of blood clotting time in the dormant hamster. Science, Wash. 115, 272.

Templeton J. R. (1971) Reptiles. In Comparative Physiology of Temperature Regulation (Edited by Whitrow G. C.), Vol. 1, pp. 167-221. Academic Press, New York.

WEAST R. C. (Editor) (1970) Handbook of Chemistry and Physics. Chemical Rubber, Cleveland.

Wells R. E. (1964) Rheology of blood in the microvasculature. New Engl. J. Med. 270 832-839. 
Wenberg G. M., Holland J. C. \& Sewell J. (1973) Some aspects of the hematology and immunology of the hibernating and non-hibernating woodchuck (Marmota monax). Comp. Biochem. Physiol. 46A, 523-535.

WILSON K. J. (1972) The relationships of activity, energy, metabolism and body temperature in four species of lizards. Ph.D. thesis, Monash University, Victoria, Australia.
Wilson K. J. \& Lee A. K. (1974) Energy expenditure of a large herbivorous lizard. Copeia 1974, 338-348.

ZAIN-UL-ABEDIN M. \& KATORSKI B. (1967) Certain blood constituents of a lizard during hibernation and activity. Can. J. Physiol. Pharm. 45, 115-119.

Key Word Index-Haematological adjustments; blood viscosity; hypothermia; torpor; haematocrit; mice; lizard; Egernia cunninghami; Peromyscus leucopus. 